\title{
Article \\ Antimicrobial Activities of Plant Extracts against Solanum tuberosum L. Phytopathogens
}

\author{
Aleksandra Steglińska ${ }^{1, *(\mathbb{D}}$, Anastasiia Bekhter ${ }^{2}$, Paweł Wawrzyniak ${ }^{3}{ }^{\oplus}$, Alina Kunicka-Styczyńska ${ }^{4}{ }^{\oplus}$, \\ Konrad Jastrząbek ${ }^{2}$, Michał Fidler ${ }^{1}$, Krzysztof Śmigielski ${ }^{1}$ and Beata Gutarowska ${ }^{1}$ (i)
}

1 Department of Environmental Biotechnology, Lodz University of Technology, Wólczańska 171/173, 90-530 Łódź, Poland; 217781@edu.p.lodz.pl (M.F.); krzysztof.smigielski@p.lodz.pl (K.Ś.); beata.gutarowska@p.lodz.pl (B.G.)

2 Institute of Natural Products and Cosmetics, Lodz University of Technology, Stefanowskiego 2/22, 90-537 Łódź, Poland; anastasiia.bekhter@dokt.p.lodz.pl (A.B.); konrad.jastrzabek@p.lodz.pl (K.J.)

3 Faculty of Process and Environmental Engineering, Lodz University of Technology, Wólczańska 213, 90-924 Łódź, Poland; pawel.wawrzyniak@p.lodz.pl

4 Department of Sugar Industry and Food Safety Management, Lodz University of Technology, Wólczańska 171/173, 90-530 Łódź, Poland; alina.kunicka@p.lodz.pl

* Correspondence: aleksandra.steglinska@dokt.p.lodz.pl

check for updates

Citation: Steglińska, A.; Bekhter, A.; Wawrzyniak, P.; Kunicka-Styczyńska, A.; Jastrząbek, K.; Fidler, M.;

Śmigielski, K.; Gutarowska, B. Antimicrobial Activities of Plant Extracts against Solanum tuberosum L. Phytopathogens. Molecules 2022, 27, 1579. https://doi.org/10.3390/ molecules27051579

Academic Editor: Francesco Cacciola

Received: 28 January 2022

Accepted: 25 February 2022

Published: 27 February 2022

Publisher's Note: MDPI stays neutral with regard to jurisdictional claims in published maps and institutional affiliations.

Copyright: (C) 2022 by the authors. Licensee MDPI, Basel, Switzerland. This article is an open access article distributed under the terms and conditions of the Creative Commons Attribution (CC BY) license (https:// creativecommons.org/licenses/by/ $4.0 /)$.

\begin{abstract}
The purpose of the study was to select an environmentally friendly plant biopesticide to protect seed potatoes against phytopathogens. The scope included the evaluation of the antimicrobial activities of 22 plant water extracts, 22 water-glycol extracts, and 3 subcritical carbon dioxide extracts using the agar diffusion method against 10 potato phytopathogens. For the most effective extracts, minimal inhibitory concentration (MIC), chemical composition analysis by gas chromatography-mass spectrometry and in situ assays on seed potatoes were performed. Garlic water extract was finally selected as the most effective in phytopathogen growth inhibition, both in vitro and in situ, with MIC values ranging between $6.3-25 \mathrm{mg} / \mathrm{mL}$. 5-Hydroxymethylfurfural was determined to be the main component of this extract (33.24\%). Garlic water extract was proposed as a potential biopesticide against potato phytopathogens.
\end{abstract}

Keywords: plant extracts; natural compounds; garlic extract; clove extract; thyme extract; subcritical carbon dioxide extraction; biopesticide; potato seeds; plant pathogens

\section{Introduction}

Potato (Solanum tuberosum L.) is the third-most consumed food plant in the world, following wheat and rice. World potato production is growing constantly [1]. Poland is the seventh-largest producer in the world and the second-largest in Europe. The harvest in 2020 was estimated at 9 million tons, which is $40 \%$ more than the harvest in 2019 , while the cultivation area was about 300,000 ha [2]. Crop pathogens (phytopathogens) reduce the quality and yield of agricultural production. They are responsible for huge economic losses and reduce food security nationally and globally. In the case of potatoes, yield losses are estimated at $17.2 \%$ worldwide [3]. Unfavourable climatic changes (heat and droughts) increase the sensitivity of crops to phytopathogen infestations [1].

The most dangerous bacterial phytopathogens of potato tubers are Clavibacter michiganensis subsp. Michiganensis, causing bacterial ring rot disease [4]; Pectobacterium carotovorum, the cause of soft rot [5]: Ralstonia solanacearum, leading to potato wilting: and Streptomyces scabiei, inducing the potato common scab [6]. In turn, the main fungal phytopathogens are Fusarium spp., associated with Fusarium dry rot; Rhizoctonia solani; Colletotrichum coccodes; and the Alternaria and Phoma exigua moulds, which develop during potato storage [7-10].

The basis of healthy seed potato production is prevention by the elimination of infection sources, introducing crops of increased resistance and, essentially, the appropriate seed 
potato storage from harvest to plant. Seed potatoes should be stored in optimal temperature $\left(3-4{ }^{\circ} \mathrm{C}\right.$ ) and humidity (90-95\%). These storage conditions prevent potato mass decline, chemical composition change, loss after germination, and, importantly, microorganism infestation [11] during several months of storage. Although synthetic fungicides effective against phytopathogens exist, their excessive usage leads to the development of phytopathogen resistance to chemicals and long-term negative effects on human health $[12,13]$. Nowadays, the global trend seems to be a shift towards reducing the use of synthetic fungicides, and thus there is a strong and growing tendency to seek safer and more ecological alternatives to combat plant diseases.

An environmentally friendly solution may be the use of plant extracts. These are composed of the plant cells' secondary metabolites. Although the quality and quantity of these compounds depend on plant species, environmental growth conditions, pathogen incidence, harvesting season, and method of extraction, their biopesticidal characteristics are usually broad and targeted against a variety of plant pathogens. Moreover, they are biodegradable and do not cause severe harm to the environment. Therefore, plant extracts can serve as a natural alternative to synthetic fungicides for potato treatment against post-harvest storage phytopathogens $[13,14]$.

In order to obtain plant extracts containing the desired bioactive compounds, it is important to select the appropriate extraction method. The common solvents used for extraction, such as hexane, methanol, acetone, and chloroform, are carcinogenic; therefore, they should not be used in products for crop protection. This research focused mainly on water and glycol-water extraction, which remain safe to human health [15]. The addition of the sonification process allows the receipt of a higher yield of extraction because of plant cellwall destruction. The most common method of obtaining essential oils is steam distillation although it causes the decomposition of compounds that are sensitive to temperature [14]. An alternative may be a supercritical carbon dioxide extraction, a novel-and recognised as green-technology of plant extraction. Avoidance of thermal degradation, as well as solvent contamination, is the main advantage of this method [15]. Several studies reported the successful usage of this technique to prepare extracts from Thymus vulgaris [16], Satureja montana [17], and Borago officinalis L. [18].

Plant extracts that are reported to exhibit antimicrobial activity against potato phytopathogens from genus Fusarium include Caryophyllus aromaticus L. (clove), Lavandula angustifolia L. (lavender), Mentha piperita L. (peppermint), Rosmarinus officinalis L. (rosemary) and Thymus vulgaris L. (thyme) extracts [19]. Rhizoctonia solani development inhibition was confirmed in several studies for Nigella sativa L. (blackseed) [20], Allium sativum L. (garlic) [21], Urtica dioica L. (nettle) [9], Allium cepa L. (onion) [22], and Salvia officinalis L. (sage) [23]. Alternaria species growth was inhibited as shown in previous studies by Carum carvi L. (caraway) [24], Allium sativum L. [25], Thymus vulgaris L. [26], and Curcuma longa L. (turmeric) [25]. Carum carvi L. has been additionally mentioned as a Pectobacterium carotovorum growth inhibition agent [27].

In the study, we performed an extensive screening of plant extracts with potential for application as biopesticides for potato protection against phytopathogens, aiming to select the optimal extraction method in terms of antimicrobial properties and economic efficiency. Moreover, the compounds of the extracts that most effectively inhibited the growth of phytopathogens were identified, and application tests were performed on seed potatoes. The operating range included the evaluation of the antimicrobial properties of 22 water plant extracts, 22 water-glycol plant extracts, and 3 plant extracts obtained by subcritical carbon dioxide extraction (SCDE) against 10 seed-potato phytopathogens. The most effective plant extracts were chosen: 2 water and 2 SCDE extracts and their chemical characteristics and MIC values. In situ tests of the selected extracts were performed on seed potatoes. 


\section{Results and Discussion}

\subsection{In Vitro Evaluation of Antimicrobial Activities of Plant Extracts against Potato Phytopathogens}

The antimicrobial activity of 22 water plant extracts (WE), 22 water-glycol plant extracts (WGE) and the subcritical $\mathrm{CO}_{2}$ extracts (SCDE) of 3 plants, namely blackseed, thyme, and caraway, were tested against 10 potato phytopathogens.

The susceptibility to phytopathogens varied greatly and was influenced by the pathogenextract relationship. It was shown that eight out of all tested water extracts inhibited the growth of at least one strain of potato phytopathogen: sage, blackseed, thyme, garlic, clove, onion, turmeric, and bistort (Figure 1). The zones of phytopathogen growth inhibition ranged from $1.0 \pm 0.0 \mathrm{~mm}$ (blackseed WE extract against $A$. tenuissima) up to $57.6 \pm 0.6 \mathrm{~mm}$ (clove WE against $R$. solani). Garlic and clove WE have demonstrated the broadest spectrum of antimicrobial activity, inhibiting the growth of all 10 tested phytopathogens.

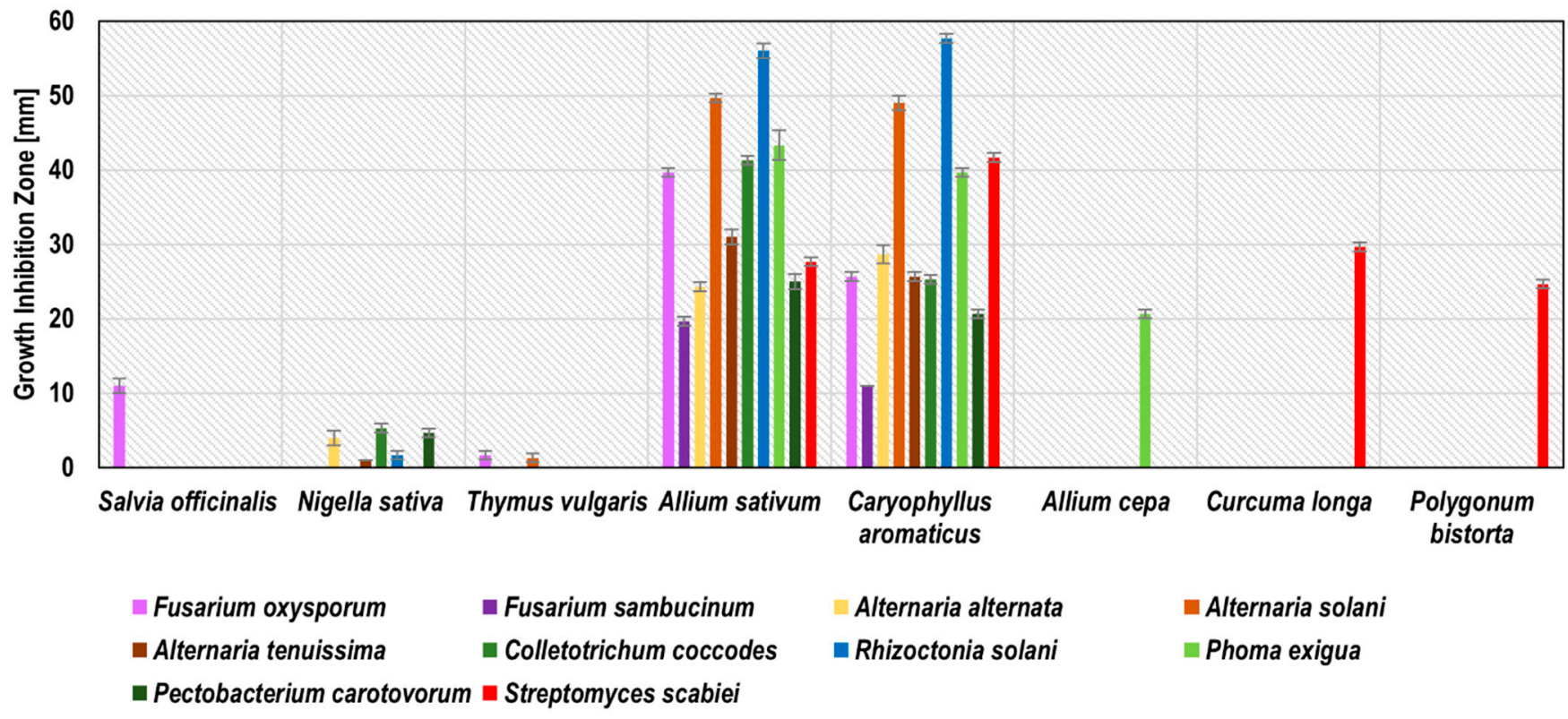

Figure 1. Activity of plant water extracts against potato seed phytopathogens measured as growth inhibition zones in the agar-well diffusion method. The graph only includes plants that showed inhibition of at least one phytopathogen.

The antibacterial property of garlic extracts against several human pathogens, including Pseudomonas aeruginosa, Staphylococcus aureus, Escherichia coli, Salmonella spp., and Streptococcus mutans has already been described [28-32]. Although the activity of garlic extracts against potato phytopathogens is under-reported, a garlic WE was active against Alternaria solani [33], while chloroform, hexane, methanol [34], and water [22] extracts inhibited the growth of Rhizoctonia solani. In our work, garlic WE was active against F. oxysporum $(19.7 \pm 0.6 \mathrm{~mm})$ and against $R$. solani $(56.0 \pm 1.0)$. To the best of our knowledge, there are no literature data on clove WE activity against potato phytopathogens. Several studies, however, have reported the antifungal activities of clove essential oil and ethanol-water extracts against potato phytopathogens. Clove essential oil exhibited antifungal activity against F. oxysporum $[19,21,35,36]$ and Alternaria alternata [37], while ethanol-water extract inhibited the growth of Rhizoctonia solani [20]. In our study, the phytopathogen growth inhibition zones caused by clove WE ranged from $11.0 \pm 0.0 \mathrm{~mm}$ against $F$. sambucinum to $57.6 \pm 0.6 \mathrm{~mm}$ against $R$. solani.

The most susceptible phytopathogens to garlic and clove WE were the moulds $R$. solani and $A$. solani, while the weakest activities of these extracts were demonstrated against $F$. sambucinum and P. carotovorum. Based on Ponce et al. [38], garlic and clove extracts were considered to be active (inhibition zone diameter $9-15 \mathrm{~mm}$; clove WE against F. sambucinum) 
or very active (inhibition zone diameter $>15 \mathrm{~mm}$; the other combinations of extract and phytopathogen). Onion WE against P. exigua $(20.1 \pm 0.6 \mathrm{~mm})$ as well as turmeric and bistort WE against $S$. scabiei (29.7 \pm 0.6 and $24.6 \pm 0.6 \mathrm{~mm}$, respectively) were recognized as very active. According to several studies, the growth of $R$. solani might be inhibited by turmeric [25], nettle [9], sage [9,22,23], and onion water extracts [22]; however, our study indicates no activity of these extracts against $R$. solani.

On the contrary, our observations confirmed Abd-El-Khair et al. [22], who point out that peppermint WE was inactive against $R$. solani. An earlier study also reported the antifungal activity of blackseed ethanol-water extract against $R$. solani [20], probably due to the addition of ethanol as a solvent, enriching the extract in active compounds. Discrepancies in antifungal activity may result from differences in the chemical composition of individual extracts depending on plant variety, storage methods, or the exact extraction procedure. The detailed results of phytopathogen growth inhibition by water extracts are presented in Figure 1 and Table S1.

Glycol-water plant extracts expressed a wider range of activity compared to the water extracts of the same plant. All of the 22 glycol-water extracts revealed antimicrobial activity against at least one strain of the phytopathogens tested (Figure 2). The zones of growth inhibition ranged from $1.0 \pm 0.0 \mathrm{~mm}$ (caraway WGE against A. alternata) to $59.0 \pm 1.0 \mathrm{~mm}$ (clove WGE against $A$. solani). As in the case of water extracts, the most active glycol-water extracts were garlic and clove, which inhibited the growth of 9 (no activity against F. sambucinum) and 10 phytopathogens, respectively. The zones of growth inhibition estimated for garlic WGE ranged from $25.7 \pm 0.6$ against $P$. carotovorum to $51.0 \pm 1.0 \mathrm{~mm}$ against $P$. exigua and $A$. solani. For clove WGE, these values ranged from $26.3 \pm 0.6 \mathrm{~mm}$ against $P$. carotovorum to $59.0 \pm 1.0 \mathrm{~mm}$ against $A$. solani. The most sensitive phytopathogens to these two glycol-water extracts were A. solani, P. exigua, R. solani, and C. coccodes, while the least sensitive were P. carotovorum and A. alternata. The following WGE were classified as very active: turmeric against $A$. solani, C. coccodes, $R$. solani, P. exigua, and S. scabiei; bistort against A. alternata, C. coccodes, P. exigua, and P. carotovorum; common knotgrass against $A$. alternata, $P$. carotovorum, and $S$. scabiei; sage and rosemary against $R$. solani and S. scabiei; peppermint against $R$. solani; horsetail, hop, and summer savoury against $S$. scabiei; onion against $P$. carotovorum. No studies were found regarding glycolwater extracts against potato phytopathogens. This article is the first such extensive research in this field. Previous studies reported inhibition of $A$. alternata growth by peppermint and lavender methanol-water extract [10] and peppermint essential oil [26]; however, due to a different type of extract, these findings were not reflected in the present work. The detailed results of phytopathogen growth inhibition by water-glycol extracts are presented in Figure 2 and Table S2. 


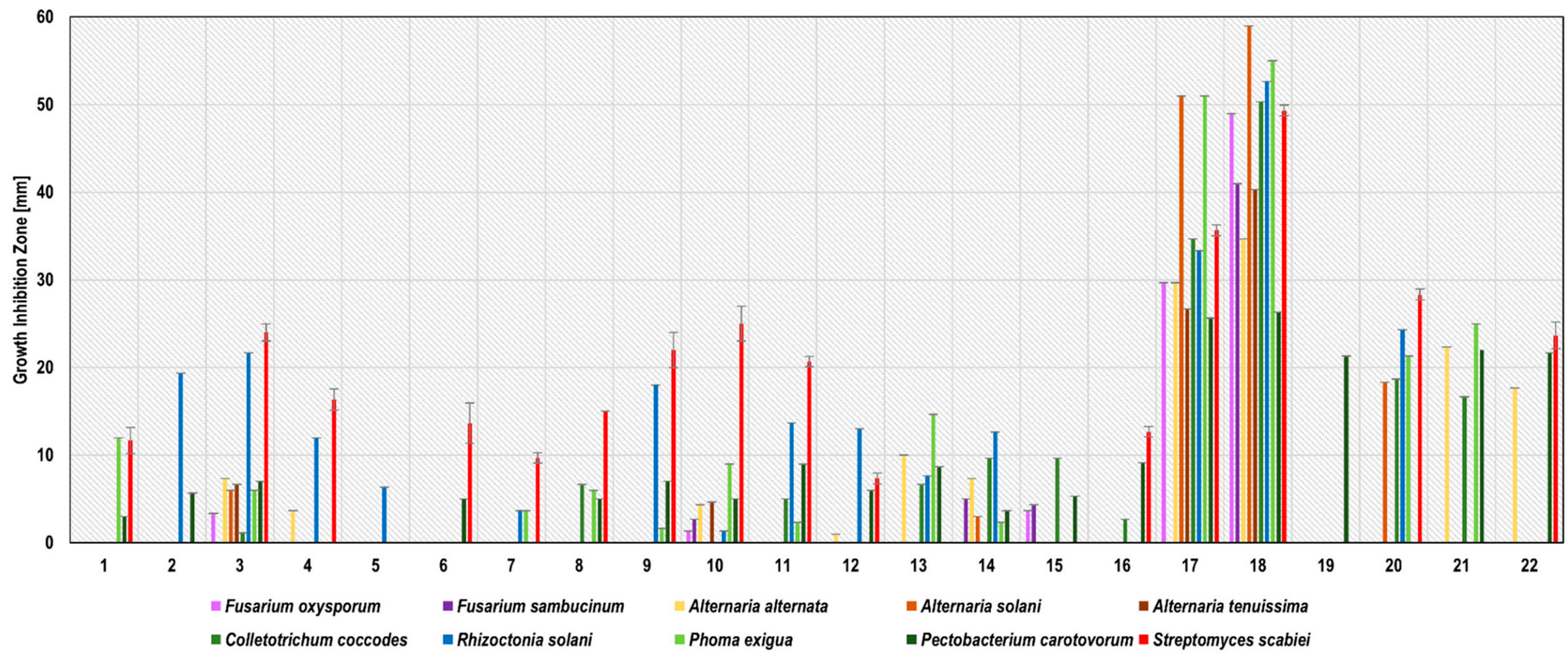

Figure 2. Activity of plant glycol-water extracts against potato seed phytopathogens measured as growth inhibition zones in the agar-well diffusion method. 1-common yarrow; 2-peppermint; 3-sage; 4-common horsetail; 5-nettle; 6-dandelion; 7-couch grass; 8-perforate St. John's wort; 9-rosemary; 10-common hop; 11—summer savoury; 12—caraway; 13-blackseed; 14—thyme; 15-lavender; 16-horseradish; 17—garlic; 18—clove; 19—onion; 20—turmeric; 21—bistort; and 22—common knotgrass. 
Blackseed, thyme, and caraway subcritical carbon dioxide extracts (SCDE) were tested against potato phytopathogens. Only these three plants were successfully used for subcritical carbon dioxide extraction, probably due to the high level of oil fraction in the seeds of these plants. All of these SCDEs inhibited the growth of at least six phytopathogens (Figure 3). The growth inhibition zones ranged from $3.1 \pm 0.6 \mathrm{~mm}$ for the blackseed SCDE against A. solani to $48.4 \pm 1.7 \mathrm{~mm}$ for the thyme SCDE against P. exigua. Thyme SCDE showed the broadest spectrum of antimicrobial activity by inhibiting the growth of all 10 phytopathogens tested. The most susceptible to thyme SCDE were P. exigua ( $48.4 \pm 1.7 \mathrm{~mm})$, R. solani, C. coccodes, and F. sambucinum (45.2 \pm 1.5 , $45.2 \pm 1.5$, and $45.0 \pm 0.6 \mathrm{~mm}$, respectively), while the least susceptible were P. carotovorum and A. tenuissima ( $10.0 \pm 1.0$ and $13.2 \pm 0.6 \mathrm{~mm}$, respectively). Our research confirmed the antifungal activity of thyme SCDE against $A$. alternata, as previously described by Perina et al. [39], Soković et al. [26], and Puškárová et al. [37] for thyme essential oil/mL. Zambonelli et al. [40] indicated the antifungal activity of thyme essential oil against $R$. solani, which coincides with our results for thyme SCDE. Diánez et al. [19] present the antifungal activity of thyme essential oil against $F$. oxysporum, which is compatible with our research for thyme SCDE. Caraway SCDE inhibited the growth of eight phytopathogens. The best effect was observed against $A$. alternata (growth inhibition zone $15.3 \pm 0.6 \mathrm{~mm}$ ) and P. exigua (growth inhibition zone $12.6 \pm 0.6 \mathrm{~mm}$ ). Convergent results were obtained in previous studies for caraway essential oil, for which antimicrobial activity has been demonstrated against P. carotovorum [27] and A. alternata [24]. Blackseed SCDE inhibited the growth of six phytopathogens, with the largest inhibition zones against $\mathrm{S}$. scabiei $(19.2 \pm 1.2 \mathrm{~mm})$ and C. coccodes $(16.1 \pm 1.2 \mathrm{~mm})$. Based on Ponce et al. [28], thyme SCDE was considered as active against eight tested pathogens (F. oxysporum, F. sambucinum, A. alternaria, A. solani, C. coccodes, R. solani, P. exigua, and S. scabiei); caraway SDCE was recognised as very active against $A$. alternata, and blackseed SCDE against $C$. coccodes and $S$. scabiei. The detailed results of phytopathogen growth inhibitions by SCDE are presented in Figure 3 and Table S3.

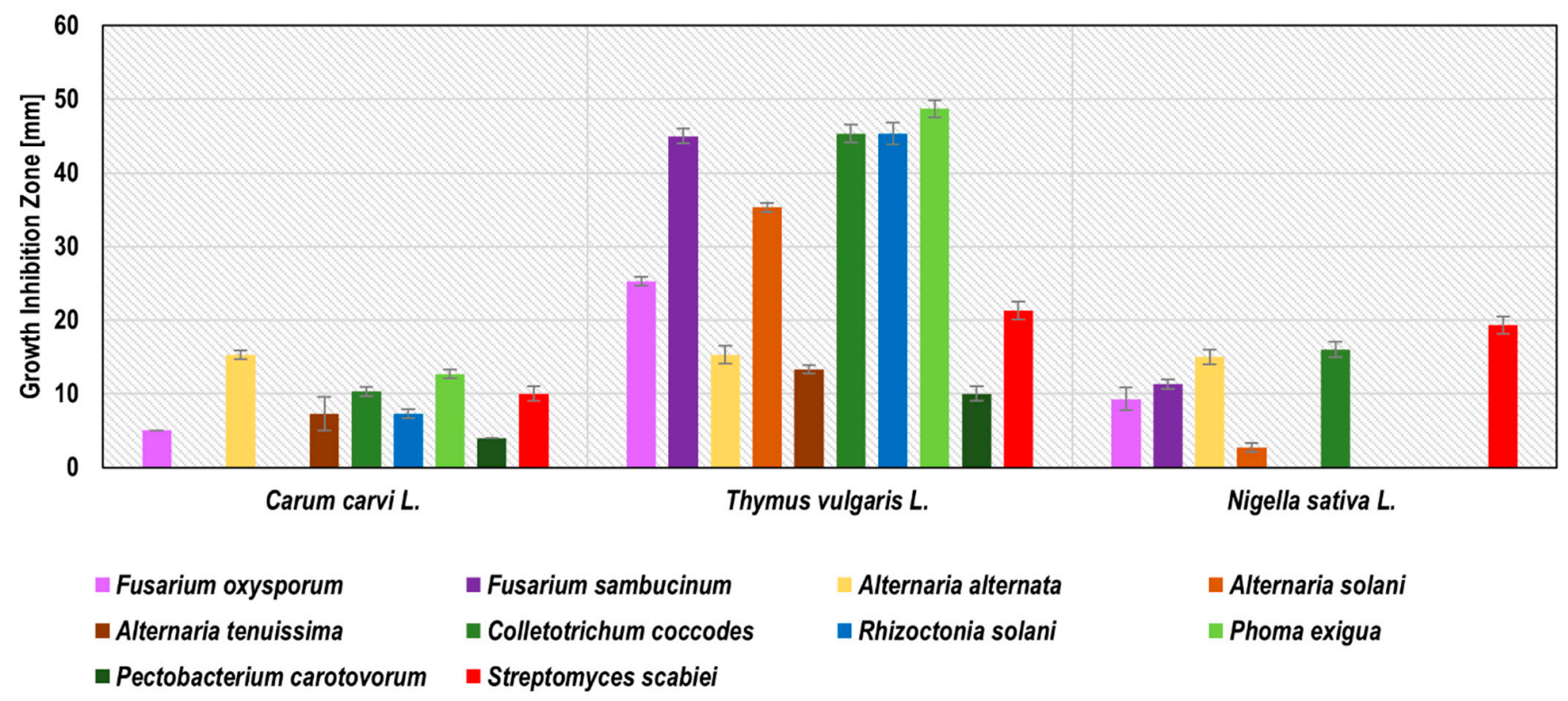

Figure 3. Activity of plant subcritical carbon dioxide extracts (SCDE) extracts against potato seed phytopathogens measured as growth inhibition zones in the agar-disc diffusion method.

Glycol-water extracts exhibited in general a wider spectrum of activity against the potato phytopathogens than water extracts. The exceptions were garlic and clove extracts, which inhibited a similar number of pathogens regardless of the solvent used. The greatest differences in antimicrobial activity were observed for SCDE thyme extracts compared to both WE and WGE. Thyme SCDE was recognized as active or very active against all 
10 tested phytopathogens, while both WGE and WE only against 2 pathogens. These differences were similar for caraway and blackseed SCDE (active or very active against 4 and 5, respectively) in comparison to WE (not active or very active), but smaller for WGE (active against 1 and 3 pathogens, respectively).

The Minimal Inhibitory Concentration (MIC) and Minimal Bactericidal/Fungicidal Concentration (MBC/MFC) were determined for garlic and clove water extracts and for thyme and caraway subcritical $\mathrm{CO}_{2}$ extracts that were the most effective against the phytopathogens. Further experiments on glycol-water extracts were abandoned due to their negative impact on the morphological features of seed potatoes (data not published). The detailed results are presented in Table 1.

Table 1. MIC and MBC/MFC values of selected water and subcritical carbon dioxide extracts (SCDE) against potato phytopathogens.

\begin{tabular}{|c|c|c|c|c|c|c|}
\hline \multirow{4}{*}{ Phytopathogens } & \multicolumn{4}{|c|}{ Water Extracts } & \multicolumn{2}{|c|}{ SCDE } \\
\hline & \multicolumn{2}{|c|}{ Allium sativum } & \multicolumn{2}{|c|}{ Caryophyllus aromaticus } & \multirow{2}{*}{$\begin{array}{r}\text { Thymus vulgaris } \\
\text { MI }\end{array}$} & \multirow[t]{2}{*}{ Carum carvi } \\
\hline & $\operatorname{MIC}^{a}$ & MBC/MFC & $\operatorname{MIC}^{a}$ & MBC/MFC & & \\
\hline & \multicolumn{4}{|c|}{$[\mathrm{mg} / \mathrm{mL}]$} & \multicolumn{2}{|c|}{$[\mathrm{mg} / \mathrm{mL}$ EtOH] } \\
\hline Fusarium oxysporum & 12.5 & 25.0 & 6.3 & 12.5 & 5.7 & 22.5 \\
\hline Fusarium sambucinum & 12.5 & 25.0 & 3.1 & 12.5 & 5.7 & nd \\
\hline Alternaria alternata & 25.0 & 25.0 & 6.3 & nd & 11.5 & 90.0 \\
\hline Alternaria solani & 6.3 & 25.0 & 3.1 & 6.3 & 5.7 & nd \\
\hline Alternaria tenuissima & 25.0 & nd & 6.3 & 12.5 & 11.5 & 90.0 \\
\hline Colletotrichum coccodes & 12.5 & 25.0 & 6.3 & 12.5 & 2.9 & 45.0 \\
\hline Rhizoctonia solani & 12.5 & 12.5 & 3.1 & 6.3 & 5.7 & 45.0 \\
\hline Phoma exigua & 6.3 & 12.5 & 3.1 & 6.3 & 11.5 & 90.0 \\
\hline Pectobacterium carotovorum & 25.0 & 25.0 & 6.3 & 25.0 & 5.7 & 90.0 \\
\hline Streptomyces scabiei & 12.5 & 25.0 & 3.1 & 12.5 & 2.9 & 90.0 \\
\hline
\end{tabular}

a_determined by the macro-broth dilution method; ${ }^{b}$-determined by the agar-disc diffusion method, MIC-Minimal Inhibitory Concentration; MBC/MFC—Minimal Bactericidal Concentration/Minimal Fungicidal Concentration; nd-not detected.

MIC values of garlic WE vary between 6.3 and $25 \mathrm{mg} / \mathrm{mL}$, and the most sensitive were the moulds A. solani and P. exigua (MIC $6.3 \mathrm{mg} / \mathrm{mL}$ ), followed by F. oxysporum, F. sambucinum, C. coccodes, R. solani and Gram-positive bacteria S. scabiei (MIC $12.5 \mathrm{mg} / \mathrm{mL}$ ). The growth inhibition of two moulds of the genus Alternaria: A. alternata and A. tenuissima, as well as bacteria P. carotovorum, was possible at a garlic WE concentration not lower than $25 \mathrm{mg} / \mathrm{mL}$. The lower MIC value of garlic WE compared to Gram-negative bacteria $P$. carotovorum was noted against other representatives of the Enterobacteriaceae family, E. coli and Salmonella typhi, by Iwalokun et al. [41] (MIC 20.8 and $21.8 \mathrm{mg} / \mathrm{mL}$, respectively). In the same study, MIC values for S. aureus and Streptococcus pneumoniae were 27.1 and $30.3 \mathrm{mg} / \mathrm{mL}$, respectively, which is more than two times higher than those obtained in our work for S. scabiei, another representative of Gram-positive bacteria. In the present work, MBC/MFC values of garlic WE ranged from 12.5 to $25 \mathrm{mg} / \mathrm{mL}$ against the tested microorganisms, with the exception of A. tenuissima, for which no MFC was detected.

MIC values of clove WE were found to be 50 to $75 \%$ lower than those of garlic WE and vary between 3.1 and $6.3 \mathrm{mg} / \mathrm{mL}$ for all the phytopathogens tested. On the contrary, the MBC/MFC values were more diversified. The lowest were recorded against $A$. solani, R. solani, and P. exigua $(6.3 \mathrm{mg} / \mathrm{mL})$, and the highest against P. carotovorum $(25 \mathrm{mg} / \mathrm{mL})$. As mentioned above, there are no previously reported data on clove WE activity against potato phytopathogens. There are, however, some reports on clove essential oil action against selected fungi. Puškárová et al. [37] have not estimated the MFC value (MIC was equal to $0.025 \%$ ) of clove essential oil against $A$. alternata, which is similar to our results on MFC determination obtained for clove WE (in our work, MIC was 252 times higher). Rana et al. [36] determined the MIC of clove essential oil against F. oxysporum as equal to 
$10 \mu \mathrm{L} / \mathrm{mL}$, about 630 times lower than that observed in our work for clove WE. In another study, Sharma et al. [21] reported MIC $31.25 \mathrm{ppm}$ and MFC $125 \mathrm{ppm}$ of clove essential oil against F. oxysporum, 2016 and 1000 times lower than the values obtained in the present work for clove WE, respectively. The weaker antifungal action of clove WE compared to clove essential oil may be attributed to the higher concentration of antifungal components in pure essential oil than in water extract.

MIC values of thyme SCDE ranged between 2.9 and $11.5 \mathrm{mg} / \mathrm{mL}$. The lowest MIC values were recorded against $C$. coccodes and $S$. scabiei $(2.9 \mathrm{mg} / \mathrm{mL})$, while the highest were against $A$. alternata, $A$. tenuissima, and $P$. exigua $(11.5 \mathrm{mg} / \mathrm{mL})$. In the earlier studies of Puškárová et al. [37] and Soković et al. [26], however, thyme essential oil revealed antifungal activity at a much lower concentration (MIC $0.025 \%$ and MIC $0.25 \mu \mathrm{L} / \mathrm{mL}$, respectively). It can be assumed that this is related to the differences in the qualitative and quantitative composition of the essential oil and the subcritical carbon dioxide extract.

The MIC values for caraway SCDE were the highest of all the extracts tested. The growth of five phytopathogens (A. alternata, A. tenuissima, P. exigua, P. carotovorum, and $S$. scabiei) was inhibited by only $0.9 \mathrm{mg} / \mathrm{mL}$ undiluted extract. The lowest value was observed against $F$. oxysporum, and the minimum inhibitory concentration was $22.5 \mathrm{mg} / \mathrm{mL}$. The MIC values of caraway SCDE against $P$. carotovorum and A. alternata recorded in this work were significantly higher than the values of caraway essential oil obtained in the work of Iacobellis et al. [27] $(910 \mu \mathrm{g})$ and Begum et al. [24] (50 ppm).

Due to the high activity and broad spectrum of action, in terms of future research on seed potatoes, we recommend the use of water extracts from garlic and clove, as well as caraway and thyme subcritical carbon dioxide extracts. The use of other extracts that exhibited high antimicrobial activity but not against such a wide phytopathogen spectrum is also worth considering, e.g., onion WE (antifungal activity against P. exigua), turmeric and bistort WE (against S. scabiei), and blackseed SCDE (against C. coccodes and S. scabiei).

\subsection{Chemical Composition of Selected Extracts}

The chemical composition of garlic and clove water extracts, as well as that of thyme and caraway subcritical carbon dioxide extracts, was identified. The results are presented in Tables 2-5.

Table 2. Volatile compounds of Allium sativum L. water extract.

\begin{tabular}{ccc}
\hline Component & KI & Composition [\%] \\
\hline Acetaldehyde & & 5.17 \\
Methyl mercaptan & 512 & 0.36 \\
Propionaldehyde & 557 & 1.60 \\
2-Methylpropanal & 584 & 0.88 \\
Butane-2,3-dione & 599 & 0.32 \\
Allyl mercaptan & 650 & 3.52 \\
3-Methylbutanal & 655 & 4.27 \\
Acetic acid & 676 & 1.93 \\
1-Hydroxypropan-2-one & 688 & 5.46 \\
1-(Methylthio)prop-1-ene & 742 & 0.22 \\
Methyl prop-2-enoate & 752 & 0.21 \\
3-Hydroxypropanal & 765 & 0.25 \\
Mercaptoacetone & 804 & 1.68 \\
Furan-2-carboxaldehyde & 840 & 7.09 \\
Furan-2-methanol & 841 & 0.25 \\
Diallyl sulphide & 866 & 0.30 \\
Dihydrofuran-2(3H)-one & 888 & 0.56 \\
Allyl propyl sulphide & 894 & 0.38 \\
Methyl prop-2-enyl disulphide & 897 & 0.44 \\
3-Methylfuran-2(5H)-one & 918 & 1.19 \\
1-(Ethylthio)-2-methylprop-1-ene & 929 & 0.17 \\
5-Methylfuran-2-carboxaldehyde & & 0.81 \\
\hline
\end{tabular}


Table 2. Cont.

\begin{tabular}{ccc}
\hline Component & KI & Composition [\%] \\
\hline Dimethyl trisulphide & 947 & 0.95 \\
2,4-Dihydroxy-2,5-dimethylfuran-3(2H)-one & 957 & 0.13 \\
3-Methylcyclopentane-1,2-dione & 995 & 0.28 \\
Benzeneacetaldehyde & 1006 & 0.43 \\
Butyl angelate & 1034 & 0.16 \\
2,5-Dimethyl-4-hydroxyfuran-3(2H)-one & 1040 & 2.25 \\
2,3-Dihydro-5-hydroxy-6-methyl-4H-pyran-4-one & 1049 & 0.51 \\
Diallyl disulphide & 1056 & 1.58 \\
Linalool & 1085 & 0.50 \\
Allyl methyl trisulphide & 1111 & 0.41 \\
Pyranone & 1118 & 3.73 \\
L-Pinocarveol & 1123 & 0.18 \\
Isoamyl angelate & 1136 & 0.10 \\
Pinocarvone & 1138 & 0.10 \\
3-Vinyl-1,2-dithiacyclohex-4-ene & 1157 & 0.44 \\
3-Vinyl-1,2-dithiacyclohex-5-ene & 1178 & 0.22 \\
5-Hydroxymethylfurfural & 1196 & 33.24 \\
(+)-Carvone & 1216 & 0.19 \\
Di-2-propenyl trisulphide & 1273 & 0.18 \\
Palmitic acid & 1772 & 0.32 \\
Total unidentified compounds & - & 16.99 \\
\hline
\end{tabular}

KI-Kovats index.

Table 3. Volatile compounds of Caryophyllus aromaticus L. water extract.

\begin{tabular}{|c|c|c|}
\hline Component & KI & Composition [\%] \\
\hline Acetaldehyde & & 0.38 \\
\hline Ethyl acetate & 618 & 0.25 \\
\hline Acetic acid & 650 & 0.22 \\
\hline 2-Methylbutanal & 659 & 0.15 \\
\hline 1-Hydroxypropan-2-one & 686 & 0.11 \\
\hline Propylene glycol & 727 & 0.24 \\
\hline Hex-3-en-1-ol & 841 & 0.65 \\
\hline Hexan-1-ol & 855 & 0.16 \\
\hline Octan-3-ol & 981 & 0.13 \\
\hline Benzeneacetaldehyde & 1008 & 0.15 \\
\hline Eucalyptol & 1019 & 0.08 \\
\hline Butyl angelate & 1035 & 0.18 \\
\hline p-Cresol & 1055 & 0.72 \\
\hline Linalool & 1085 & 0.58 \\
\hline$\alpha$-Thujone & 1097 & 0.09 \\
\hline Pyranone & 1115 & 0.18 \\
\hline Camphor & 1120 & 0.22 \\
\hline L-Pinocarveol & 1123 & 0.63 \\
\hline Camphene hydrate & 1132 & 0.09 \\
\hline Isoamyl tiglate & 1137 & 0.11 \\
\hline Pinocarvone & 1138 & 0.27 \\
\hline Borneol & 1150 & 0.33 \\
\hline Terpinen-4-ol & 1162 & 0.34 \\
\hline$\alpha$-Terpineol & 1173 & 0.42 \\
\hline Carvone & 1216 & 0.61 \\
\hline 3-Methylpentylangelate & 1236 & 0.05 \\
\hline Eugenol & 1334 & 82.39 \\
\hline Caryophyllene & 1419 & 2.49 \\
\hline$\alpha$-Humulene & 1452 & 0.23 \\
\hline Eugenol acetate & 1486 & 4.56 \\
\hline Selina-6-en-4-ol & 1641 & 0.10 \\
\hline Hexadecanoic acid & 1941 & 0.41 \\
\hline Stearic acid & 2141 & 0.11 \\
\hline Total unidentified compounds & - & 2.46 \\
\hline
\end{tabular}


Table 4. Volatile compounds of Thymus vulgaris L. subcritical carbon dioxide extract.

\begin{tabular}{|c|c|c|}
\hline Component & KI & Composition [\%] \\
\hline Methyl 2-methylbutanoate & 757 & 0.03 \\
\hline$\alpha$-Thujene & 920 & 0.14 \\
\hline$\alpha$-Pinene & 927 & 0.18 \\
\hline Camphene & 940 & 0.11 \\
\hline Oct-1-en-3-ol & 962 & 0.78 \\
\hline$\beta$-Pinene & 967 & 0.08 \\
\hline Myrcene & 980 & 0.55 \\
\hline$\alpha$-Phellandrene & 994 & 0.05 \\
\hline Car-3-ene & 1002 & 0.02 \\
\hline iso-Terpinene & 1007 & 0.52 \\
\hline p-Cymene & 1012 & 8.53 \\
\hline Eucalyptol & 1018 & 0.51 \\
\hline d-Limonene & 1019 & 0.19 \\
\hline$\gamma$-Terpinen & 1049 & 4.10 \\
\hline 4-Thujanol & 1053 & 0.87 \\
\hline p-Cymenene & 1073 & 0.02 \\
\hline Terpinolene & 1078 & 0.03 \\
\hline 4-Thujanol & 1082 & 0.14 \\
\hline Linalool & 1086 & 1.93 \\
\hline Camphor & 1119 & 0.09 \\
\hline endo-Borneol & 1149 & 0.50 \\
\hline Terpinen-4-ol & 1162 & 0.20 \\
\hline Menthol & 1170 & 0.04 \\
\hline$\alpha$-Terpineol & 1183 & 0.14 \\
\hline Thymol methyl ether & 1215 & 0.43 \\
\hline 2-isopropyl-4-methyl-anisole & 1226 & 0.31 \\
\hline Thymoquinone & 1228 & 0.04 \\
\hline (+)-Carvone & 1233 & 0.17 \\
\hline Geraniol & 1253 & 0.07 \\
\hline Thymol & 1283 & 48.54 \\
\hline Carvacrol & 1288 & 3.16 \\
\hline Copaene & 1377 & 0.05 \\
\hline$(-)-\beta$-Bourbonene & 1385 & 0.04 \\
\hline Thymohydroquinone & 1420 & 4.57 \\
\hline Caryophyllene & 1421 & 1.59 \\
\hline Geranyl propanoate & 1453 & 0.22 \\
\hline$\gamma$-Muurolene & 1472 & 0.16 \\
\hline$\beta$-Bisabolene & 1502 & 0.08 \\
\hline$\gamma$-Cadin-2-ene & 1509 & 0.25 \\
\hline cis-Calamenene & 1512 & 0.06 \\
\hline$\delta$-Cadinene & 1517 & 0.30 \\
\hline Caryophyllene oxide & 1575 & 0.59 \\
\hline Humulene epoxide II & 1598 & 0.05 \\
\hline 10-epi- $\gamma$-eudesmol & 1612 & 0.06 \\
\hline$\tau$-Cadinol & 1629 & 0.21 \\
\hline (-)-Loliolide & 1707 & 0.02 \\
\hline Oplopanone & 1712 & 0.02 \\
\hline Myristic acid & 1742 & 0.05 \\
\hline Neophytadiene & 1837 & 0.19 \\
\hline Hexadecan-1-ol & 1864 & 0.09 \\
\hline $\begin{array}{l}\text { 3,7,11,15-Tetramethylhexadec- } \\
\text { 2-en-1-ol }\end{array}$ & 1879 & 0.06 \\
\hline Hexadecanoic acid & 1960 & 5.13 \\
\hline Phytol & 2102 & 0.37 \\
\hline Oleic acid & 2133 & 6.34 \\
\hline Stearic acid & 2154 & 0.50 \\
\hline Arachidic acid & 2345 & 0.06 \\
\hline
\end{tabular}


Table 4. Cont.

\begin{tabular}{ccc}
\hline Component & KI & Composition [\%] \\
\hline Glyceryl Linolenate & 2438 & 0.07 \\
Glyceryl Monooleate & 2444 & 0.19 \\
Squalene & 2805 & 0.21 \\
Nonacosane & 2881 & 0.33 \\
Triacontane & 3068 & 0.17 \\
Vitamin E & 3084 & 0.43 \\
$\gamma$-Sitosterol & 3324 & 0.33 \\
Total unidentified compounds & - & 4.74 \\
\hline
\end{tabular}

KI-Kovats index.

Table 5. Volatile compounds of Carum carvi L. subcritical carbon dioxide extract.

\begin{tabular}{|c|c|c|}
\hline Component & KI & Composition [\%] \\
\hline (+)-Sabinene & 963 & 0.03 \\
\hline Myrcene & 980 & 0.25 \\
\hline d-Limonene & 1025 & 37.17 \\
\hline Car-3-ene & 1037 & 0.05 \\
\hline$\gamma$-Terpinen & 1048 & 0.04 \\
\hline Linalool & 1084 & 0.05 \\
\hline Trans-p-mentha-2,8-dienol & 1103 & 0.08 \\
\hline Cis-limonene oxide & 1116 & 0.14 \\
\hline Trans-Limonene oxide & 1120 & 0.09 \\
\hline Menthol & 1158 & 0.05 \\
\hline Trans-dihydrocarvone & 1178 & 0.08 \\
\hline Trans-carveol & 1208 & 0.11 \\
\hline (+)-Carvone & 1227 & 52.14 \\
\hline (E)-Citral & 1245 & 0.02 \\
\hline Perillaldehyde & 1248 & 0.24 \\
\hline Methyl geraniate & 1302 & 0.02 \\
\hline Caryophyllene & 1419 & 0.25 \\
\hline$\alpha$-Humulene & 1452 & 0.02 \\
\hline Germacrene & 1478 & 0.02 \\
\hline Caryophyllene oxide & 1573 & 0.04 \\
\hline Neophytadiene & 1837 & 0.09 \\
\hline Hexadecanoic acid & 1947 & 1.19 \\
\hline Phytol & 2100 & 0.04 \\
\hline Linoleic acid & 2117 & 1.82 \\
\hline Oleic acid & 2130 & 3.34 \\
\hline Octadecanoic acid & 2147 & 0.22 \\
\hline Arachidic acid & 2344 & 0.03 \\
\hline 2-Glyceryl linoleate & 2387 & 0.06 \\
\hline 2,3-Dihydroxypropyl elaidate & 2394 & 0.12 \\
\hline Glyceryl linolenate & 2438 & 0.23 \\
\hline Glyceryl monooleate & 2445 & 0.57 \\
\hline Squalene & 2805 & 0.24 \\
\hline Nonacosane & 2881 & 0.34 \\
\hline Total unidentified compounds & - & 0.81 \\
\hline
\end{tabular}

KI-Kovats index.

A total of 33 (97.54\%) compounds of clove water extract were identified and eugenol (allylbenzene class of chemical compounds) was determined to be the main component $(82.39 \%)$. This result is in accordance with the results reported for different types of clove extracts by many authors. In other studies, eugenol constituted 53.9\% [42], 75.41\% [21], or even $85 \%$ [35] of clove oil and $52.88 \%$ of subcritical $\mathrm{CO}_{2}$ extract [43] and was the principal compound in all of them. The eugenol content indicated in the literature was a result of both the origin of the plant material and the fact that the analytical method used (GC-MS) gives the relative content of the ingredients, and not the actual one. This is confirmed by 
the lower content of eugenol in carbon dioxide extract (52,88\%) because this extraction method shows the full organic profile of the plant matrix and consequently a greater number of compounds. The relative content of eugenol was therefore lower in carbon dioxide extract than in essential oils of clove. The presented investigation also revealed the presence of eugenol acetate (4.56\%) and caryophyllene (2.49\%). These compounds are also reported in the above-mentioned studies of clove extracts in different concentrations. It is well documented that the antimicrobial activity of clove extracts is mostly related to high eugenol content, and the mode of action is based on cytoplasmic membrane disruption, inhibition of some microbial enzymes, and the negative effect of ions and ATP transport [44].

A total of $42(83.01 \%)$ components of garlic water extract were identified, and 5hydroxymethylfurfural (33.24\%) was observed in the highest quantity. This compound was previously found in black garlic subjected to heat treatment [45] and in three Chinese varieties of fresh garlic (4.88, 26.78 and $47.10 \%)$; however, no antimicrobial activity has yet been reported for 5-hydroxymethylfurfural. No allicin was observed in our garlic WE, probably due to its instability and quick transformation into other sulphur components [46]. Small quantities of diallyl disulphide (1.58\%), dimethyl trisulphide $(0.95 \%)$, 3-vinyl-1,2dithiacyclohex-4-ene $(0.44 \%)$, allyl methyl trisulphide $(0.41 \%)$, and others were determined and might be jointly responsible for the strong antimicrobial activity of garlic WE against the tested potato phytopathogens [13].

In total, $63(95.26 \%)$ of the components of thyme subcritical $\mathrm{CO}_{2}$ extract were identified and thymol (monoterpenoid phenol derivative of $p$-cymene; $48.54 \%$ ) was determined to be dominant. This result is confirmed by numerous studies, which verify the presence of thymol in thyme essential oils at a level of 39.14 [47], 47.9 [48], and 48.9\% [26]. Some studies [49] reported another monoterpenoid phenol, thymol isomer carvacrol, as a major component of thyme essential oil, which in the current study was present at a level of $3.16 \%$. Also, the presence of $p$-cymene ( $8.53 \%$ ) was reported in the above-mentioned studies. The antimicrobial activity of thymol and carvacrol is revealed in the work of Perina et al. [39] and Sim et al. [50]. Their mode of antimicrobial action included the disruption of cell walls, leading to leakage of cell components and, consequently, to lysis. Other reported mechanisms include disturbances in protein synthesis and quorum sensing [51].

Based on $33(99.19 \%)$ of the compounds identified in caraway subcritical $\mathrm{CO}_{2}$ extract, (+)-carvone (terpenoid; 52,14\%) and D-limonene (cyclic monoterpene; 37.17\%) were determined as the two main components. These results are similar to those obtained by Iacobellis et al. [27], where carvone (23.3\%) and limonene (18.2\%) were detected as the principal components of caraway essential oil; however, other compounds found in high quantities in this work, such as germacrene and trans-dihydrocarvone, were found only in traces in the caraway SCDE in the present study. Also, Argañosa et al. [52] and Putievsky et al. [53] indicated carvone and limonene as the dominant components in caraway essential oil. A different composition, however, was reported by Begum et al. [24], where thymol $(48.20 \%)$, o-cymene $(19.29 \%)$, and $\gamma$-terpinen $(17.61 \%)$ were the main components.

\subsection{In Situ Evaluation of Antimicrobial Activities of Selected Plant Extracts against Potato Phytopathogens}

The in situ antimicrobial activities of garlic and clove WE, as well as those of caraway and thyme SCDE, on seed potatoes were evaluated. The results are presented in Table 6 and Figure 4. 
Table 6. Reduction of potato seed cv. Impresja infestation treated with selected plant extracts against potato phytopathogens.

\begin{tabular}{|c|c|c|c|c|}
\hline \multirow{3}{*}{ Phytopathogens } & \multicolumn{4}{|c|}{ Reduction of Potato Infestation [\%] } \\
\hline & \multicolumn{2}{|c|}{ Water Extracts } & \multicolumn{2}{|c|}{ SCDE } \\
\hline & Allium sativum $\mathbf{L}$. & Caryophyllus aromaticus L. & Thymus vulgaris L. & Carum carvi $\mathbf{L}$. \\
\hline Fusarium oxysporum & 100.0 & $88.9 \pm 1.97$ & $33.3 \pm 1.88$ & $55.6 \pm 0.63$ \\
\hline Fusarium sambucinum & 100.0 & 0.0 & nd & nd \\
\hline Alternaria alternata & 0.0 & 0.0 & nd & nd \\
\hline Alternaria solani & 100.0 & $+25.0 \pm 0.0 *$ & nd & nd \\
\hline Alternaria tenuissima & 0.0 & 100.0 & nd & nd \\
\hline Colletotrichum coccodes & 100.0 & $+10.0 \pm 2.89 *$ & $55.6 \pm 3.1$ & $83.3 \pm 1.89$ \\
\hline Rhizoctonia solani & 100.0 & $+93.8 \pm 1.64$ * & nd & nd \\
\hline Phoma exigua & 100.0 & $+95.0 \pm 0.0 *$ & nd & nd \\
\hline $\begin{array}{c}\text { Pectobacterium } \\
\text { carotovorum }\end{array}$ & 0.0 & 0.0 & 0.0 & 0.0 \\
\hline Streptomyces scabiei & 100.0 & $+75.0 \pm 2.5^{*}$ & nd & nd \\
\hline
\end{tabular}

nd-not determined; * - potato infestation increase.

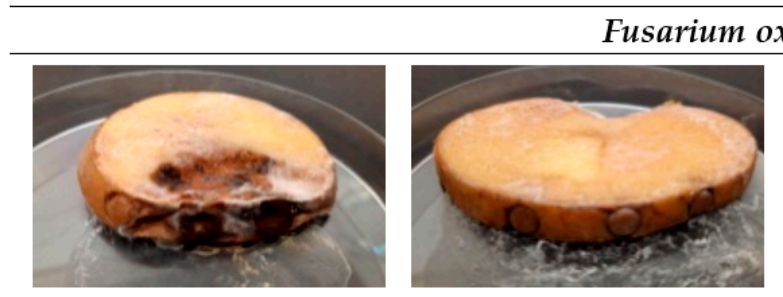

Allium satioum L.

Control sample water extract

Reduction $=100 \%$

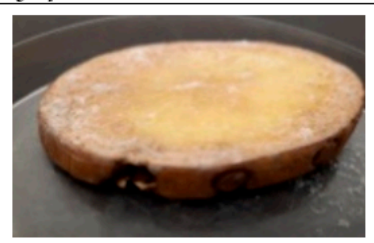

Caryophyllus aromaticus $\mathrm{L}$. water extract Reduction $=88.9 \% \pm$ 1.97

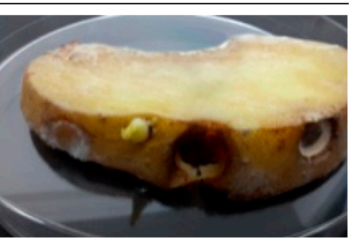

Carum carvi $\mathrm{L}$. SCDE

Reduction $=55.6 \% \pm$ 0.63

\begin{tabular}{ccc}
\hline \multicolumn{3}{c}{ Colletotrichum coccodes } \\
\hline
\end{tabular}

Figure 4. Inhibition of F. oxysporum and C. coccodes infestation of potatoes cv. Impresja treated with plant extracts.

The in situ assay revealed that garlic WE reduced potato infestation of F. oxysporum, F. sambucinum, A. solani, C. coccodes, R. solani, P. exigua, and S. scabiei. It was, however, ineffective against $A$. alternata, $A$. solani, and $P$. carotovorum, while the in vitro assay performed using the agar-well diffusion method indicated significant growth inhibition. Nashwa et al. [33] reported lower reduction of $A$. solani growth on tomatoes (61.7 and 71.7\% reduction), but the WE concentrations of garlic used were also lower ( 1 and $5 \%$, respectively). In our work, a 100\% reduction of A. solani infestation was achieved by non-diluted garlic WE. 
Clove WE treatment inhibited F. oxysporum (88.9\%) and A. tenuissima (100\%) infestation of seed potatoes satisfactorily in the in situ assay. This treatment, however, increased the spread of $A$. solani (+25\%), C. coccodes (+10\%), R. solani (+93.8\%), P. exigua (+95\%) and S. scabiei $(+75 \%)$, even though the in vitro assessment of clove WE by the agar-well diffusion method demonstrated positive results of pathogen growth inhibition. Similar findings were reported by Muñoz Castellanos et al. [35] for clove essential oil, where the oil at a lower concentration (350 ppm) reduced F. oxysporum growth on tomatoes more effectively than at 450 ppm. Opposite results are reported for $\mathrm{CO}_{2}$ clove extract by Šernaitè et al. [43], where the clove SCDE, at a concentration of $6 \mathrm{~mL} / \mathrm{L}$, increased the infection of grey mould on strawberry leaves, while at a twice-higher concentration significantly reduced it.

The antimicrobial activity of thyme and caraway SCDEs at concentrations equal to exact MIC values was tested against three seed potato phytopathogens. The extracts demonstrated reduction of F. oxysporum (33.3 and 55.6\%, respectively) and C. coccodes (55.6 and $83.3 \%$, respectively) infestation on seed potatoes but were totally ineffective against $P$. carotovorum bacteria ( $0 \%)$. To the best of our knowledge, the antimicrobial effects of thyme and caraway extracts against seed potato phytopathogens have not yet been studied in in situ assays. Nikkhah et al. [47], however, reported on the antifungal activity of thyme essential oil in a concentration equal to $625 \mu \mathrm{g} / \mathrm{mL}$ against Botrytis cinerea, which causes spoilage on pear fruit.

\section{Materials and Methods}

\subsection{Plant Material and Extracts Preparation}

Plant material from 22 different plants, presented in Table 7, was purchased from Dary Natury Sp. z o. o., Grodzisk, Poland and Zakład Zielarski KAWON-HURT Nowak sp.j., Gostyń, Poland.

Table 7. Plant material used for the preparation of extracts.

\begin{tabular}{|c|c|c|}
\hline Latin Name & Common Name & Part of the Plant \\
\hline Achillea millefolium L. & Common yarrow & Leaves, stems \\
\hline Mentha piperita L. & Peppermint & Leaves, stems \\
\hline Salvia officinalis L. & Sage & Leaves, stems \\
\hline Equisetum arvense L. & Common horsetail & Leaves, stems \\
\hline Urtica dioica L. & Nettle & Leaves, stems \\
\hline Taraxacum officinale (L.) Weber ex F.H. Wigg. & Dandelion & Leaves, stems \\
\hline Elymus repens (L.) Gould & Couch grass & Leaves, stems \\
\hline Hypericum perforatum L. & Perforate St. John's wort & Root \\
\hline Rosmarinus officinalis Spenn. & Rosemary & Leaves, stems \\
\hline Humulus lupulus L. & Common hop & Inflorescences \\
\hline Satureja hortensis L. & Summer savoury & Leaves, stems \\
\hline Carum carvi L. & Caraway & Seeds \\
\hline Nigella sativa L. & Blackseed & Seeds \\
\hline Thymus vulgaris L. & Thyme & Seeds \\
\hline Lavandula angustifolia Mill. & Lavender & Flower buds \\
\hline Armoracia rusticana G. Gaertn., B. Mey. \& Scherb. & Horseradish & Root \\
\hline Allium satioum $\mathrm{L}$. & Garlic & Bulb \\
\hline Syzygium aromaticum (L.) Merr. \& Perry & Clove & Flower buds \\
\hline Allium cepa $\mathrm{L}$. & Onion & Bulb \\
\hline Curcuma longa L. & Turmeric & Root \\
\hline Polygonum bistorta L. & Bistort & Leaves, stems \\
\hline Polygonum aviculare & Common knotgrass & Leaves, stems \\
\hline
\end{tabular}

\subsubsection{Water Extracts (WE)}

Twenty grams of finely ground plant material was poured into $200 \mathrm{~mL}$ of water at $100{ }^{\circ} \mathrm{C}$ and left covered without stirring for $1 \mathrm{~h}$. The obtained extracts were then sonicated $\left(40 \mathrm{kHz}, 25^{\circ} \mathrm{C}\right)$ for $30 \mathrm{~min}$ and filtered under reduced pressure. 


\subsubsection{Water-Glycol Extracts (WGE)}

Eight grams of ground plant material was poured into $200 \mathrm{~mL}$ of extractant 1:4 water: propylene glycol $(v / v)$ (Chempur, Piekary Śląskie, Poland) and stirred for $3 \mathrm{~h}$ at room temperature. The obtained extracts were then sonicated $\left(40 \mathrm{kHz}, 25^{\circ} \mathrm{C}\right)$ for $30 \mathrm{~min}$ and filtered under reduced pressure.

\subsubsection{Subcritical Carbon Dioxide Extracts (SCDE)}

The extraction was performed in an apparatus designed and constructed at the Faculty of Process and Environmental Engineering at the Lodz University of Technology, Poland. Between 64.5 and $101.4 \mathrm{~g}$ of finely ground seed powder was poured into a $280 \mathrm{cc}$ stainless steel pressure extraction vessel. The system was operated at a constant pressure of $31.4 \pm 0.02 \mathrm{MPA}$, with the temperature maintained at $28 \pm 1^{\circ} \mathrm{C}$. A liquid $\mathrm{CO}_{2}$ pump provided a constant carbon dioxide flow at a rate of $7 \mathrm{cc} / \mathrm{min}$, while an automatic back pressure regulator controlled pressure within the extraction vessel. The extract was collected in a glass trap after reduction of $\mathrm{CO}_{2}$ pressure to $0.1 \mathrm{MPa}$. The whole extraction process lasted for $\sim 6 \mathrm{~h}$, which was sufficient for complete extraction. In all experiments, the ratio of $\mathrm{CO}_{2}$ used for extraction to the weight of the raw material was between 25 and 30 .

\subsection{Potato Phytopathogens}

The fungal species Colletotrichum coccodes DSM 62126, Phoma exigua DSM 62040, Fusarium sambucinum DSM 62397, Rhizoctonia solani DSM 22843, Alternaria tenuissima DSM 63,360, and the bacterial species Streptomyces scabiei DSM 40,778 were obtained from the German Collection of Microorganisms and Cell Cultures GmbH (DSMZ, Braunschweig, Germany). Pectobacterium carotovorum PCM 2056 was purchased from the Polish Collection of Microorganisms of the Hirszfeld Institute of Immunology and Experimental Therapy of the Polish Academy of Sciences (Wrocław, Poland). Alternaria alternata ŁOCK 408 was acquired from the Collection of Pure Cultures of Industrial Microorganisms ŁOCK at the Lodz University of Technology (Łódź, Poland). Alternaria solani Z184 and Fusarium oxysporum Z154 isolates were kindly provided by Prof. Jadwiga Śliwka from the Plant Breeding and Acclimatization Institute (IHAR) - National Research Institute (Radzików, Poland). Strains were cultivated on Potato Dextrose Agar-PDA (Merck, Darmstadt, Germany) for moulds, and on Tryptic Soy Agar-TSA (Merck, Darmstadt, Germany) for bacteria, and stored at $4{ }^{\circ} \mathrm{C}$.

The spore suspension of fungal strains was prepared by washing out spores from the surface of the pure culture on the PDA medium into $0.85 \% \mathrm{NaCl}$ with Tween $(0.02 \%)$ and adjusted to $10^{6} \mathrm{CFU} / \mathrm{mL}$. Bacterial suspension was prepared from the pure culture on the TSA medium and adjusted to $10^{6} \mathrm{CFU} / \mathrm{mL}$.

\subsection{In Vitro Antimicrobial Assay}

The antimicrobial activity of water and water-glycol plant extracts was determined by the agar-well diffusion method. Freshly prepared fungal and bacterial suspensions of $100 \mu \mathrm{L}$ were inoculated onto PDA (for moulds) or TSA (for bacteria) plates. Then, wells $10 \mathrm{~mm}$ in diameter were cut by a sterile cork bore and $250 \mu \mathrm{L}$ of extracts were introduced into the wells. Water or a water-glycol mixture was used as a control. The plates were incubated for $2-5$ days (depending on the pathogen) at $25^{\circ} \mathrm{C}$. The diameters of the phytopathogen growth inhibition zones were measured, excluding the well diameters. The results were expressed as the average of three independent repetitions for each pathogenextract combination with a standard deviation value.

The antimicrobial activity of subcritical carbon dioxide extracts was determined by the agar-disc diffusion method. Freshly prepared fungal and bacterial suspensions of $100 \mu \mathrm{L}$ were inoculated onto PDA (for moulds) or TSA (for bacteria) plates. Then, sterile discs $6 \mathrm{~mm}$ in diameter were placed on the plates, and $5 \mu \mathrm{L}$ of the extracts were applied on the discs. The plates were incubated for $2-5$ days (depending on the pathogen) at $25^{\circ} \mathrm{C}$. The diameters of phytopathogen growth inhibition zones were measured, excluding the disc 
diameters. The results were expressed as the average of three independent repetitions for each pathogen-extract combination with a standard deviation value.

Antimicrobial activity was assessed based on Ponce et al. [28]; the diameter of the growth inhibition zone $<8$ was considered as an inactive substance, $9-15 \mathrm{~mm}$ as an active substance, and $>15 \mathrm{~mm}$ as a very active substance.

\subsection{Minimal Inhibitory Concentration (MIC) and Minimal Bactericidal/Fungicidal Concentration (MBC/MFC) Determination}

MIC values for garlic and clove water extracts were examined using the macro-broth dilution method. One $\mathrm{mL}$ of each extract was serially diluted in $1 \mathrm{~mL}$ of malt extract broth medium-MEB (Merck, Darmstadt, Germany) for moulds or tryptic soy broth-TSB (Merck, Darmstadt, Germany) for bacteria to reduce concentration from 50 to $0.098 \mathrm{mg} / \mathrm{mL}$. Then, $1 \mathrm{~mL}$ of fresh fungal or bacterial suspension was added to test tubes and incubated for 1 to 3 days (depending on the pathogen) at $25^{\circ} \mathrm{C}$. The visible growth of phytopathogens was assessed in order to determine the MIC value. The cultures were inoculated onto malt extract agar-MEA (Merck, Darmstadt, Germany) or a TSA medium in order to determine MBC/MFC values. The cidal effect was noted when no growth on the MEA or TSA plates was observed. For each pathogen-diluted extract combination, three repetitions were performed.

MIC values for caraway and thyme subcritical carbon dioxide extracts were assessed by the agar-disc diffusion method. Extracts were serially diluted in $96 \%$ ethanol $(\mathrm{POCH}$, Gliwice, Poland) in order to reduce concentration from 91.7 to $0.09 \mathrm{mg} / \mathrm{mL}$. Freshly prepared fungal and bacterial suspensions of $100 \mu \mathrm{L}$ were inoculated onto PDA (for moulds) or TSA (for bacteria) plates. Then, sterile discs $6 \mathrm{~mm}$ in diameter were placed on the plates and $5 \mu \mathrm{L}$ of the diluted extracts was applied on each disc. Ninety-six percent (1:2 diluted, $v / v$ ) ethanol was used as a control. Plates were incubated for 2-5 days (depending on the pathogen) at $25^{\circ} \mathrm{C}$. Pathogen growth around the discs was assessed and MIC values were determined. The MIC value was noted for the lowest extract concentration for which a growth inhibition zone was still observed. For each pathogen-diluted extract combination, 3 repetitions were performed.

\subsection{Gas Chromatography with Flame Ionisation Detector and Mass Spectrometry of Selected Extracts}

Analyses were conducted in a Thermo Ultra GC Trace equipped with a flame ionisation detector and a Thermo DSQ II mass spectrometer (split flow). An Rxi ${ }^{\circledR}-1$ ms $(60 \mathrm{~m} \times 0.25 \mathrm{~mm} \times 0.25 \mu \mathrm{m}$ film thickness) column from RESTEK was used. The injector temperature was $280^{\circ} \mathrm{C}$, and the detector temperature (FID) was $300^{\circ} \mathrm{C}$. The MS temperatures were as follows: transfer line, $280^{\circ} \mathrm{C}$ and ion source, $220^{\circ} \mathrm{C}$. The scan range operated between $20 \mathrm{U}$ and $250 \mathrm{U}$ (from $2.50 \mathrm{~min}$ to $4.90 \mathrm{~min}$ ) and between $13 \mathrm{U}$ and $250 \mathrm{U}$ (above $4.90 \mathrm{~min}$ ). The oven was programmed at $50^{\circ} \mathrm{C}$, held for $3 \mathrm{~min}$; then, a $4{ }^{\circ} \mathrm{C} / \mathrm{min}$ increase ramped the temperature to $310^{\circ} \mathrm{C}$, where it remained for $10 \mathrm{~min}$. The injection quantity was $1 \mu \mathrm{L}$ with $15 \mathrm{~mL} / \mathrm{min}$ split for water extract samples, and $0.5 \mu \mathrm{L}$ with $100 \mathrm{~mL} / \mathrm{min}$ split for $\mathrm{CO}_{2}$ extract samples. The carrier gas (He) flow was kept constant at $300 \mathrm{kPa}$. Based on electron spectra from the NIST 2011 library and the Kovats index, the studied analyte was identified. The volatile compounds were identified.

\subsection{In Situ Antimicrobial Assay on Seed Potatoes}

Healthy seed potatoes cv. Impresja obtained from Zamarte Potato Breeding (Zamarte, Poland) were rinsed in sterile distilled water and left to dry in air for $1 \mathrm{~h}$. Three $5 \mathrm{~mm}$ in diameter and $5 \mathrm{~mm}$ deep cuts were made on each potato using a sterile cork bore. Then, the potatoes were immersed in the extracts and left to dry for $2 \mathrm{~h}$. After that, $20 \mu \mathrm{L}$ of each fungal or bacterial suspension was applied to the cuts. Control potatoes were immersed in 
sterile $0.85 \% \mathrm{NaCl}$. After 2 weeks of incubation at $25^{\circ} \mathrm{C}$, the percentage of phytopathogen infestation was measured in comparison to the controls according to Equation (1):

$$
\text { Reduction }(\%)=\frac{C-T}{C} \times 100
$$

where $C$ is the \% of phytopathogen infestation on control potatoes and $T$ is the $\%$ of phytopathogen infestation on potatoes treated with extracts. The percentage of the infested area was measured after cutting the seed potatoes in half. The experiments were conducted in triplicate.

\subsection{Statistical Analysis}

Statistical analysis was carried out with Statistica 13.1 (Statsoft, Tulsa, OK, USA). The antimicrobial activity (phytopathogen growth inhibition zones) of all tested plants among three different types of extracts was compared using a one-way analysis of variance (ANOVA) at a significance level of 0.05. When a statistical difference was detected $(p<0.05)$, the means were compared using Tukey's post hoc procedure at a significance level of 0.05 .

\section{Conclusions}

Our research showed that water extracts obtained from sage, garlic, clove, onion, turmeric, and bistort contain compounds that are active against at least one species of potato phytopathogens. The greatest potential for use in the development of a protection regimen for seed potatoes during storage was demonstrated by garlic water extract. It exhibited its broad spectrum of antimicrobial activity against phytopathogens in vitro and its highest degree of phytopathogen growth reduction in situ. A significant advantage of using water extracts is also the low cost of their production. Due to differences in the antimicrobial activity of garlic water extract against potato phytopathogens in vitro and in situ, further research should focus on modifying the methods of applying the extract in order to obtain a wider spectrum of action.

Supplementary Materials: The following supporting information can be downloaded online, Table S1: Activity of plant water extracts against potato seed phytopathogens measured as growth inhibition zones in the agar-well diffusion method; Table S2: Activity of plant glycol-water extracts against potato seed phytopathogens measured as growth inhibition zones in the agar-well diffusion method; Table S3: Activity of plant subcritical carbon dioxide extracts against potato seed phytopathogens measured as growth inhibition zones in the agar-disc diffusion method.

Author Contributions: Conceptualisation, A.S., A.K.-S., K.Ś. and B.G.; Formal analysis, A.S. and K.J.; Funding acquisition, B.G.; Investigation, A.S., A.B., P.W., K.J. and M.F.; Methodology, A.S., A.B., P.W., A.K.-S. and K.J.; Resources, P.W., K.Ś. and B.G.; Supervision, B.G.; Validation, A.S., A.K.-S. and B.G.; Visualisation, A.S., A.K.-S. and B.G.; Writing—original draft, A.S.; Writing—review and editing, A.K.-S. and B.G. All authors have read and agreed to the published version of the manuscript.

Funding: This research was funded by the Agency for Restructuring and Modernization of Agriculture, Poland, grant number 00010.DDD.6509.00016.2018.05. The APC was funded by the Lodz University of Technology.

Institutional Review Board Statement: Not applicable.

Informed Consent Statement: Not applicable.

Acknowledgments: The authors express their gratitude to Jadwiga Sliwka from the Plant Breeding and Acclimatization Institute-National Research Institute, Poland for kindly providing strains of potato pathogens. We also acknowledge the help of Krzysztof Kołodziejczyk with plant material preparation, the help of Małgorzata Okrasa with statistical analysis, as well as Anna Rygała and Weronika Cieciura-Włoch for their assistance in antimicrobial activity determination. This article was completed while the first author was a Doctoral Candidate in the Interdisciplinary Doctoral School at the Lodz University of Technology, Poland. 
Conflicts of Interest: The authors declare no conflict of interest. The funders had no role in the design of the study; in the collection, analyses, or interpretation of data; in the writing of the manuscript; or in the decision to publish the results.

\section{References}

1. Stokstad, E. The new potato. Science 2019, 363, 574-577. [CrossRef] [PubMed]

2. Niszczota, S.; Miziołek, D. Wynikowy szacunek głównych ziemiopłodów rolnych i ogrodniczych w 2020 r. [eng. The Resulting Estimate of the Main Agricultural and Horticultural Crops in 2020.]. In GUS; 2020. Available online: https:/ / stat.gov.pl/obszary-tematyczne/rolnictwo-lesnictwo/uprawy-rolne-i-ogrodnicze/wynikowy-szacunek-glownychziemioplodow-rolnych-i-ogrodniczych-w-2020-roku,5,19.html (accessed on 28 November 2021).

3. Savary, S.; Willocquet, L.; Pethybridge, S.J.; Esker, P.; McRoberts, N.; Nelson, A. The global burden of pathogens and pests on major food crops. Nat. Ecol. Evol. 2019, 3, 430-439. [CrossRef] [PubMed]

4. Sagcan, H.; Turgut Kara, N. Detection of potato ring rot pathogen Clavibacter michiganensis subsp. sepedonicus by loop-mediated isothermal amplification (LAMP) assay. Sci. Rep. 2019, 9, 20393. [CrossRef]

5. Muturi, P.; Yu, J.; Maina, A.N.; Kariuki, S.; Mwaura, F.B.; Wei, H. Bacteriophages isolated in China for the control of Pectobacterium carotovorum causing potato soft rot in Kenya. Virol. Sin. 2019, 34, 287-294. [CrossRef]

6. Liu, J.; Nothias, L.-F.; Dorrestein, P.C.; Tahlan, K.; Bignell, D.R.D. Genomic and metabolomic analysis of the potato common scab pathogen Streptomyces scabiei. ACS Omega 2021, 6, 11474-11487. [CrossRef]

7. A'Hara, D. Detection and identification of Phoma pathogens of potato. In Plant Pathology, 2nd ed.; Lacomme, C., Ed.; Springer: Berlin, Germany, 2015; Volume 1302, pp. 17-27.

8. Mejdoub-Trabelsi, B.; Ben Abdallah, R.A. Bio-suppression of Fusarium wilt disease in potato using nonpathogenic potatoassociated fungi. J. Plant Pathol. Microbiol. 2016, 7, 347-354. [CrossRef]

9. Tapwal, A.; Garg, S.; Gautam, N.; Kumar, R. In Vitro antifungal potency of plant extracts against five phytopathogens. Brazilian Arch. Biol. Technol. 2011, 54, 1093-1098. [CrossRef]

10. Zaker, M.; Mosallanejad, H. Antifungal activity of some plant extracts on Alternaria alternata, the causal agent of Alternaria leaf spot of potato. Pakistan J. Biol. Sci. 2010, 13, 1023-1029. [CrossRef]

11. Pinhero, R.G.; Yada, R.Y. Postharvest storage of potatoes. In Advances in Potato Chemistry and Technology, 2nd ed.; Singh, J., Kaur, L., Eds.; Elservier: Amsterdam, The Netherlands, 2016; pp. 283-314.

12. Lushchak, V.I.; Matviishyn, T.M.; Husak, V.V.; Storey, J.M.; Storey, K.B. Pesticide toxicity: A mechanistic approach. EXCLI J. 2018, 17, 1101-1136. [CrossRef]

13. Jiménez-Reyes, M.F.; Carrasco, H.; Olea, A.F.; Silva-Moreno, E. Natural compounds: A sustainable alternative to the phytopathogens control. J. Chil. Chem. Soc. 2019, 64, 4459-4465. [CrossRef]

14. Šernaitè, L. Plant extracts: Antimicrobial and antifungal activity and appliance in plant protection (Review). Sodininkystės ir Daržininkystè 2017, 36, 58-68.

15. Arumugham, T.; Rambabu, K.; Hasan, S.W.; Show, P.L.; Rinklebe, J.; Banat, F. Supercritical carbon dioxide extraction of plant phytochemicals for biological and environmental applications-A review. Chemosphere 2021, 271, 129525. [CrossRef] [PubMed]

16. Grosso, C.; Figueiredo, A.C.; Burillo, J.; Mainar, A.M.; Urieta, J.S.; Barroso, J.G.; Coelho, J.A.; Palavra, A.M.F. Composition and antioxidant activity of Thymus vulgaris volatiles: Comparison between supercritical fluid extraction and hydrodistillation. J. Sep. Sci. 2010, 33, 2211-2218. [CrossRef] [PubMed]

17. Grosso, C.; Oliveira, A.C.; Mainar, A.M.; Urieta, J.S.; Barroso, J.G.; Palavra, A.M.F. Antioxidant Activities of the Supercritical and Conventional Satureja montana Extracts. J. Food Sci. 2009, 74, C713-C717. [CrossRef]

18. Casas-Cardoso, L.; Mantell, C.; Obregón, S.; Cejudo-Bastante, C.; Alonso-Moraga, Á.; de la Ossa, E.J.M.; de Haro-Bailón, A. Health-promoting properties of borage seed oil fractionated by supercritical carbon dioxide extraction. Foods 2021, $10,2471$. [CrossRef] [PubMed]

19. Diánez, F.; Santos, M.; Parra, C.; Navarro, M.J.; Blanco, R.; Gea, F.J. Screening of antifungal activity of 12 essential oils against eight pathogenic fungi of vegetables and mushroom. Lett. Appl. Microbiol. 2018, 67, 400-410. [CrossRef] [PubMed]

20. Al-Askar, A.; Rashad, Y. Efficacy of some plant extracts against Rhizoctonia solani on pea. J. Plant Prot. Res. 2010, 50, 239-243. [CrossRef]

21. Sharma, A.; Rajendran, S.; Srivastava, A.; Sharma, S.; Kundu, B. Antifungal activities of selected essential oils against Fusarium oxysporum f. sp. lycopersici 1322, with emphasis on Syzygium aromaticum essential oil. J. Biosci. Bioeng. 2017, 123, 308-313. [CrossRef]

22. Abd-El-Khair, H.; El-Gamal Nadia, G. Effects of aqueous extracts of some plant species against Fusarium solani and Rhizoctonia solani in Phaseolus vulgaris plants. Arch. Phytopathol. Plant Prot. 2011, 44, 1-16. [CrossRef]

23. Al-Baldawy, M.S.M.; Matloob, A.A.A.H.; Almammory, M.K.N. Effect of plant extracts and biological control agents on Rhizoctonia solani Kuhn. IOP Conf. Ser. Earth Environ. Sci. 2021, 735, 012079. [CrossRef]

24. Begum, J.; Bhuiyan, M.N.I.; Chowdhury, J.U.; Hoque, M.N.; Anwar, M.N. Antimicrobial activity of essential oil from seeds of Carum carvi and its composition. Bangladesh J. Microbiol. 2008, 25, 85-89. [CrossRef]

25. Masih, H.; Peter, J.K.; Tripathi, P. A comparative evaluation of antifungal activity of medicinal plant extracts and chemical fungicides against four plant pathogens. Int. J. Curr. Microbiol. Appl. Sci. 2014, 3, 97-109. 
26. Soković, M.D.; Vukojević, J.; Marin, P.D.; Brkić, D.D.; Vajs, V.; Van Griensven, L.J.L.D. Chemical composition of essential oils of Thymus and Mentha species and their antifungal activities. Molecules 2009, 14, 238-249. [CrossRef] [PubMed]

27. Iacobellis, N.S.; Lo Cantore, P.; Capasso, F.; Senatore, F. Antibacterial activity of Cuminum cyminum L. and Carum carvi L. essential oils. J. Agric. Food Chem. 2005, 53, 57-61. [CrossRef] [PubMed]

28. Daka, D. Antibacterial effect of garlic (Allium sativum) on Staphyloccus aureus: An in vitro study. African J. Biotechnol. 2011, 10, 666-669.

29. Aravind, A.; Mathai, K.; Anand, S.; Dinatius, P.; Krishnan, A.V.; Mathai, M. Antimicrobial effect of ginger, garlic, honey, and lemon extracts on Streptococcus mutans. J. Contemp. Dent. Pract. 2017, 18, 1004-1008. [CrossRef]

30. El-Azzouny, M.M.; El-Demerdash, A.S.; Seadawy, H.G.; Abou-Khadra, S.H. Antimicrobial effect of garlic (Allium sativum) and thyme (Zataria multiflora Boiss) extracts on some food borne pathogens and their effect on virulence gene expression. Cell. Mol. Biol. 2018, 64, 79-86. [CrossRef]

31. Abdulrahman, D.; Daskum, A.; Abdulrahim, K.; Dadile, A.; Amma, H. Antibacterial potency of garlic extract against certain skin pathogenic bacteria. Nov. Res. Microbiol. J. 2017, 1, 3-13. [CrossRef]

32. Meriga, B.; Mopuri, R.; MuraliKrishna, T. Insecticidal, antimicrobial and antioxidant activities of bulb extracts of Allium sativum. Asian Pac. J. Trop. Med. 2012, 5, 391-395. [CrossRef]

33. Nashwa, S.M.A.; Abo-Elyou, K.A.M. Evaluation of various plant extracts against the early blight disease of tomato plants under greenhouse and field conditions. Plant Prot. Sci. 2012, 48, 74-79. [CrossRef]

34. Choudhury, D.; Anand, Y.R.; Kundu, S.; Nath, R.; Kole, R.K.; Saha, J. Effect of plant extracts against sheath blight of rice caused by Rhizoctonia solani. J. Pharmacogn. Phytochem. 2017, 6, 399-404.

35. Muñoz Castellanos, L.; Amaya Olivas, N.; Ayala-Soto, J.; De La O Contreras, C.M.; Zermeño Ortega, M.; Sandoval Salas, F.; Hernández-Ochoa, L. In Vitro and in vivo antifungal activity of clove (Eugenia caryophyllata) and pepper (Piper nigrum L.) essential oils and functional extracts against Fusarium oxysporum and Aspergillus niger in tomato (Solanum lycopersicum L.). Int. J. Microbiol. 2020, 2020, 1702037. [CrossRef] [PubMed]

36. Rana, I.S.; Rana, A.S.; Rajak, R.C. Evaluation of antifungal activity in essential oil of the Syzygium aromaticum (L.) by extraction, purification and analysis of its main component eugenol. Brazilian J. Microbiol. 2011, 42, 1269-1277. [CrossRef] [PubMed]

37. Puškárová, A.; Bučková, M.; Kraková, L.; Pangallo, D.; Kozics, K. The antibacterial and antifungal activity of six essential oils and their cyto/genotoxicity to human HEL 12469 cells. Sci. Rep. 2017, 7, 1-11. [CrossRef]

38. Ponce, A.G.; Fritz, R.; del Valle, C.; Roura, S.I. Antimicrobial activity of essential oils on the native microflora of organic Swiss chard. LWT-Food Sci. Technol. 2003, 36, 679-684. [CrossRef]

39. Perina, F.J.; Amaral, D.C.; Fernandes, R.S.; Labory, C.R.G.; Teixeira, G.A.; Alves, E. Thymus vulgaris essential oil and thymol against Alternaria alternata (Fr.) Keissler: Effects on growth, viability, early infection and cellular mode of action. Pest Manag. Sci. 2015, 71, 1371-1378. [CrossRef]

40. Zambonelli, A.; Zechini D'Aulerio, A.; Bianchi, A.; Albasini, A. Effects of essential oils on phytopathogenic fungi in vitro. J. Phytopathol. 1996, 144, 491-494. [CrossRef]

41. Iwalokun, B.A.; Ogunledun, A.; Ogbolu, D.O.; Bamiro, S.B.; Jimi-Omojola, J. In vitro antimicrobial properties of aqueous garlic extract against multidrug-resistant bacteria and Candida species from Nigeria. J. Med. Food 2004, 7, 327-333. [CrossRef]

42. Purkait, S.; Bhattacharya, A.; Bag, A.; Chattopadhyay, R.R. Synergistic antibacterial, antifungal and antioxidant efficacy of cinnamon and clove essential oils in combination. Arch. Microbiol. 2020, 202, 1439-1448. [CrossRef]

43. Šernaitè, L.; Rasiukevičiūtè, N.; Valiuškaitè, A. The extracts of cinnamon and clove as potential biofungicides against strawberry grey mould. Plants 2020, 9, 613. [CrossRef]

44. Marchese, A.; Barbieri, R.; Coppo, E.; Orhan, I.E.; Daglia, M.; Nabavi, S.F.; Izadi, M.; Abdollahi, M.; Nabavi, S.M.; Ajami, M. Antimicrobial activity of eugenol and essential oils containing eugenol: A mechanistic viewpoint. Crit. Rev. Microbiol. 2017, 43, 668-689. [CrossRef]

45. Choi, I.; Cha, H.; Lee, Y. Physicochemical and antioxidant properties of black garlic. Molecules 2014, 19, 16811-16823. [CrossRef]

46. Ilic, D.; Nikolic, V.; Nikolic, L.; Stankovic, M.; Stanojevic, L.; Cakic, M. Allicin and related compounds: Biosynthesis, synthesis and pharmacological activity. Facta Univ.-Ser. Phys. Chem. Technol. 2011, 9, 9-20. [CrossRef]

47. Nikkhah, M.; Hashemi, M.; Habibi Najafi, M.B.; Farhoosh, R. Synergistic effects of some essential oils against fungal spoilage on pear fruit. Int. J. Food Microbiol. 2017, 257, 285-294. [CrossRef]

48. Bozin, B.; Mimica-Dukic, N.; Simin, N.; Anackov, G. Characterization of the volatile composition of essential oils of some lamiaceae spices and the antimicrobial and antioxidant activities of the entire oils. J. Agric. Food Chem. 2006, 54, 1822-1828. [CrossRef]

49. Pina-Vaz, C.; Rodrigues, A.G.; Pinto, E.; Costa-de-Oliveira, S.; Tavares, C.; Salgueiro, L.; Cavaleiro, C.; Gonçalves, M.J.; Martinezde-Oliveira, J. Antifungal activity of Thymus oils and their major compounds. J. Eur. Acad. Dermatol. Venereol. 2004, 18, 73-78. [CrossRef]

50. Sim, J.X.F.; Khazandi, M.; Chan, W.Y.; Trott, D.J.; Deo, P. Antimicrobial activity of thyme oil, oregano oil, thymol and carvacrol against sensitive and resistant microbial isolates from dogs with otitis externa. Vet. Dermatol. 2019, 30, 524. [CrossRef]

51. Kachur, K.; Suntres, Z. The antibacterial properties of phenolic isomers, carvacrol and thymol. Crit. Rev. Food Sci. Nutr. 2020, 60, 3042-3053. [CrossRef] 
52. Argañosa, G.C.; Sosulski, F.W.; Slinkard, A.E. Seed yields and essential oils of annual and biennial caraway (Carum carvi L.) hrown in western Canada. J. Herbs. Spices Med. Plants 1998, 6, 9-17. [CrossRef]

53. Putievsky, E.; Ravid, U.; Dudai, N.; Katzir, I. A New cultivar of caraway (Carum carvi L.) and its essential oil. J. Herbs. Spices Med. Plants 1994, 2, 81-84. [CrossRef] 